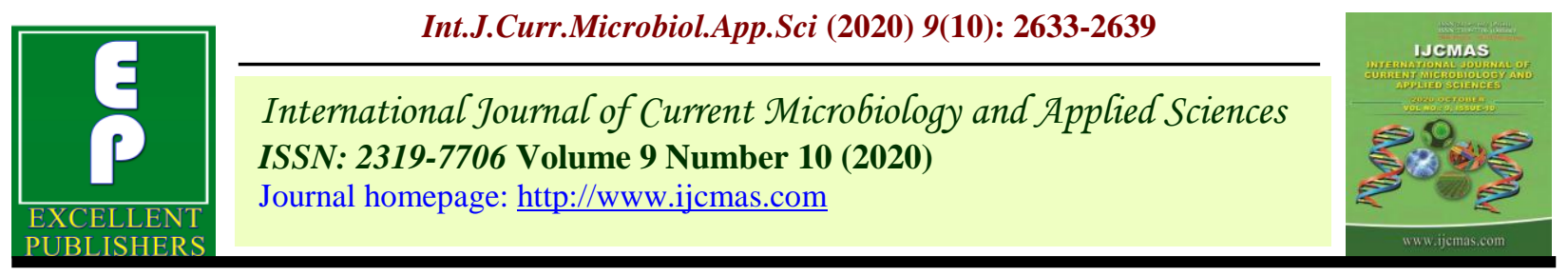

Original Research Article

https://doi.org/10.20546/ijcmas.2020.910.317

\title{
Varietal Evaluation of Gerbera (Gerbera jamesonii) under Naturally Ventilated Polyhouse Condition in Prayagraj
}

\author{
MD. Akhtar*, Devi Singh and Urfi Fatmi \\ Department of Horticulture, Naini Agricultural Institute, Sam Higginbottom University of \\ Agriculture, Technology and Sciences, Allahabad, India \\ *Corresponding author
}

\begin{abstract}
A B S T R A C T

\begin{tabular}{|l|} 
Keyw or d s \\
$\begin{array}{l}\text { Gerbera and } \\
\text { Varieties }\end{array}$ \\
\hline Article Info \\
\hline $\begin{array}{l}\text { Accepted: } \\
\text { 20 September } 2020 \\
\text { Available Online: } \\
\text { 10 October } 2020\end{array}$ \\
\hline
\end{tabular}

The present experiment was carried out during December 2019 to April 2020 in Research Field, Department of Horticulture, SHUATS, Prayagraj. The experiment was conducted in Randomized Block Design (RBD), with ten verities of Gerbera, the varieties were replicated thrice. The varieties were $V_{1}$ (Regina), $V_{2}$ (Bernika), $V_{3}$ (Martyana), $V_{4}$ (Albert), $V_{5}$ (Salsa), $V_{6}$ (Marzena), $V_{7}$ (Marta), $\mathrm{V}_{8}$ (Lisiecka), $\mathrm{V}_{9}$ (Korman) and $\mathrm{V}_{10}(\mathrm{Pal})$. Form the present investigation it is found that among the ten varieties of Gerbera. Variety Bernika found superior in Growth and yield characters followed by variety Korman and Martyana. In disc diameter and suckers yield variety Albert found superior. In vase life, Korman was superior, Minimum growth and yield was recorded in variety Marta, Pal and Regina. Maximum gross return, net return and Cost: benefit ratio was recorded in variety Bernika and minimum in variety Regina.
\end{abstract}

\section{Introduction}

Gerbera botanically known as Gerbera jamesonii belongs to the family Asteraceae. This group at present comprises 45 species, native to tropical Asia and Africa. Among the different species of gerbera viz., G. asplenifolia, G. aurantiaca G. kunzeana and G. jamesonii, the only species under cultivation is Gerbera jamesonii with chromosome number $\mathrm{n}=\mathrm{x}=25$. There are two types of gerberas, one is single, in which there are one or two rows of ray florets and the flower quality is good and another one is double type. For commercial purpose, double type are grown, which are much more in demand than the single ones. They have more than two rows of ray florets and flower quality is better than single. The leaves are petioled, entire or pinnatly lobed, coarse or sometimes tubular and two lipped. Achenes are beaked; pappus or rough bristles in two or more rows. The daisy like flowers are available in wide range of colours including yellow, red, orange, cream, white, pink, brickred, scarlet, salmon peach, maroon and various other intermediate shades.

Gerbera as a cut flower has tremendous demand in domestic and international markets. Due to globalization and increase in per capita income the demand for flowers is increasing both nationally and internationally. Though the crop can be cultivated in 
moderately warmer open sunny conditions, the performance of the crop is enhanced when grown in protected or semi-protected structures.

The main advantage of growing the crop under cover or protected conditions is exploitation of genetic potential of the genotypes. Further the crops can also be managed successfully throughout the year. Success of Gerbera under protected conditions has encouraged farmers to take up its protected cultivation extensively during the past few years in India.

\section{Materials and Methods}

The Experimental was conducted in Randomized Block Design (RBD) with 10Varieties of Gerbera with three replications in the, Research field, Department of Horticulture, Sam Higginbottom University of Agriculture, Technology and Sciences, Prayagraj during the December, 2019 to April, 2020. Total number of varieties were twelveviz. $\mathrm{V}_{1}$ (Regina), $\mathrm{V}_{2}$ (Bernika), $\mathrm{V}_{3}$ (Martyana), $\mathrm{V}_{4}$ (Albert), $\mathrm{V}_{5}$ (Salsa), $\mathrm{V}_{6}$ (Marzena), $\mathrm{V}_{7}$ (Marta), $\mathrm{V}_{8}$ (Lisiecka), $\mathrm{V}_{9}$ (Korman) and $\mathrm{V}_{10}$ (Pal). Recommended dose of manures and fertilizers were applied in each variety.

\section{Climatic condition in the experimental site}

The area of Prayagraj district comes under subtropical belt in the south east of Utter Pradesh, which experience extremely hot summer and fairly cold winter.

The maximum temperature of the location reaches up to $46^{\circ} \mathrm{C}-48^{\circ} \mathrm{C}$ and seldom falls as low as $4^{\circ} \mathrm{C}-5^{\circ} \mathrm{C}$. The relative humidity ranges between 20 to $94 \%$. The average rainfall in this area is around $1013.4 \mathrm{~mm}$ annually. However, occasional precipitation is also not uncommon during winter months.

\section{Results and Discussion}

The present investigation entitled "Varietal evaluation of Gerbera (Gerbera jamesonii) under naturally ventilated polyhouse condition" was carried out during December 2019 to April 2020 in Research Field, Department of Horticulture, Naini Agricultural Institute, Sam Higginbottom University of Agriculture, Technology and Sciences, Prayagraj (U.P.) India. The results of the present investigation, regarding the varietal evaluation of Gerbera, have been discussed and interpreted in the light of previous research work done in India and abroad. The experiment was conducted in Randomized block design with 10 Varieties, and three replications.

The results of the experiment are summarized below (Table 1 and 2).

\section{Growth parameters}

In terms of Plant height, maximum plant height $(26.21,32.29,35.19$ and $39.04 \mathrm{~cm})$ at 30, 60, 90 and 120 days was recorded in Bernika followed by variety Korman with (24.32, 29.67, 32.11 and $35.35 \mathrm{~cm})$ and minimum plant height (18.04, 21.88, 25.20 and $28.57 \mathrm{~cm}$ ) were observed in variety Pal. Plant height is a varietal character as it varies from variety to variety. Sarmah et al., (2014) reported maximum plant height in Dune $(54.70 \mathrm{~cm})$ cultivar of Gerbera.

In terms of number of leaves, maximum number of leaves $(9.50,12.27,13.81$ and 14.82) at 30, 60, 90 and 120 days was recorded in Korman followed by variety Lisiecka with (8.38 leaves in 30 DAS) variety Salsa with (11.12 leaves in 60 DAS) and variety Bernika with (12.25 and 13.48 in 90 and 120 days) and minimum number of leaves (5.98, 7.90, 9.53 and 10.88) was observed in variety Marta. The increase in number of 
leaves was probably influenced by the increased photosynthetic activity of the plants at later stages which in turn produced better vegetative growth and maximum number of leaves. The results are in accordance with the findings of Ahlawat et al., (2012) and Jangde et al., (2019) in gerbera under protected conditions.

In terms of plant spread, maximum plant spread $(32.58,37.24,43.51,49.07 \mathrm{~cm})$ at 30 , 60,90 and 120 days respectively was recorded in Bernika followed by variety Martyana with (28.83 cmin 30 DAS) and variety Korman with (23.53, 28.70 and 33.37 cmin 60, 90 and 120 days) and minimum plant spread (14.08, 17.32, 22.32 and 27.26 $\mathrm{cm})$ was observed in variety Lisiecka. The difference among the varieties may be due to bigger sized leaves produced by respective cultivars. The results are in accordance with the findings of Singh and Ramachandran
(2002), Thomas et al., (2004) and Jangde et al.,(2019).

In terms of days to first flower open, minimum number of days for first flower open (70.75) was recorded in Bernika followed by variety Korman with (73.65) and Martyana (74.41) and maximum number of days for flower open (86.35 days) was recorded in variety Marta. The early flowering in Bernika (73.65 days) might be attributed to maximum number of leaves which would have resulted in production and accumulation of more photosynthates resulting in early flowering. The data reveals that a significant variation existed in the number of days required for first flowering among the different cultivars under study. Barua and Bordoloi (2012) and Jangde et al., (2019) reported the similar results as that of the present investigation.

Table.1 Plant height $(\mathrm{cm})$ and Number of leaves/plant of Gerbera varieties under naturally ventilated polyhouse condition

\begin{tabular}{|c|c|c|c|c|c|c|c|c|c|}
\hline \multirow{2}{*}{$\begin{array}{l}\text { Variety } \\
\text { Symbol }\end{array}$} & \multirow{2}{*}{$\begin{array}{l}\text { Variety } \\
\text { Name }\end{array}$} & \multicolumn{4}{|c|}{ Plant Height (cm) } & \multicolumn{4}{|c|}{ Number of leaves/plant } \\
\hline & & $\begin{array}{c}\text { 30 } \\
\text { DAS }\end{array}$ & $\begin{array}{c}60 \\
\text { DAS }\end{array}$ & $\begin{array}{c}90 \\
\text { DAS }\end{array}$ & $\begin{array}{c}120 \\
\text { DAS }\end{array}$ & $\begin{array}{c}\text { 30 } \\
\text { DAS }\end{array}$ & $\begin{array}{c}60 \\
\text { DAS }\end{array}$ & $\begin{array}{c}90 \\
\text { DAS }\end{array}$ & $\begin{array}{c}120 \\
\text { DAS }\end{array}$ \\
\hline$V_{1}$ & Regina & 21.16 & 25.40 & 27.34 & 30.71 & 8.280 & 10.700 & 12.210 & 13.420 \\
\hline $\mathbf{V}_{2}$ & Bernika & 26.21 & 32.29 & 35.19 & 39.04 & 7.630 & 10.640 & 12.250 & 13.480 \\
\hline $\mathbf{V}_{3}$ & Martyana & 23.29 & 27.47 & 30.11 & 33.36 & 7.310 & 10.230 & 11.780 & 13.040 \\
\hline$V_{4}$ & Albert & 18.50 & 22.80 & 26.47 & 29.60 & 6.940 & 9.740 & 10.960 & 12.050 \\
\hline$V_{5}$ & Salsa & 20.86 & 24.71 & 27.40 & 30.51 & 8.130 & 11.120 & 12.240 & 13.310 \\
\hline$V_{6}$ & Marzena & 19.95 & 23.77 & 26.26 & 29.30 & 6.470 & 8.970 & 10.690 & 11.900 \\
\hline $\mathrm{V}_{7}$ & Marta & 21.80 & 26.07 & 29.05 & 31.90 & 5.980 & 7.900 & 9.530 & 10.880 \\
\hline$V_{8}$ & Lisiecka & 21.40 & 25.64 & 28.43 & 31.40 & 8.380 & 10.560 & 12.110 & 13.220 \\
\hline$V_{9}$ & Korman & 24.32 & 29.67 & 32.11 & 35.35 & 9.500 & 12.270 & 13.810 & 14.820 \\
\hline$V_{10}$ & Pal & 18.04 & 21.88 & 25.20 & 28.57 & 6.370 & 9.010 & 10.770 & 12.040 \\
\hline \multicolumn{2}{|c|}{ F-test } & $\mathrm{S}$ & $\mathrm{S}$ & S & S & $\mathrm{S}$ & S & S & S \\
\hline \multicolumn{2}{|c|}{ SE(d) } & 0.772 & 1.041 & 0.980 & 0.994 & 0.206 & 0.562 & 0.501 & 0.496 \\
\hline \multicolumn{2}{|c|}{ C.V. } & 4.387 & 4.910 & 4.176 & 3.807 & 3.371 & 6.810 & 5.275 & 4.741 \\
\hline \multicolumn{2}{|c|}{ C.D. at $5 \%$} & 1.635 & 2.204 & 2.076 & 2.104 & 0.437 & 1.191 & 1.061 & 1.050 \\
\hline
\end{tabular}


Table.2 Plant spread, Days to first flower open, Diameter of flower, disc-diameter of flower, stalk length, stalk girth, number of flowers/plant, Number of Flower/ $\mathrm{m}^{2}$, Number of suckers/plant, Vase life and Cost benefit ratio of Gerbera varieties under naturally ventilated polyhouse condition

\begin{tabular}{|c|c|c|c|c|c|c|c|c|c|c|c|c|c|c|c|}
\hline \multirow{2}{*}{$\begin{array}{l}\text { Variety } \\
\text { Symbol }\end{array}$} & \multirow{2}{*}{$\begin{array}{l}\text { Variety } \\
\text { Name }\end{array}$} & \multicolumn{4}{|c|}{ Plant Spread (cm) } & \multirow[b]{2}{*}{$\begin{array}{c}\text { Days } \\
\text { to } \\
\text { First } \\
\text { Flower } \\
\text { Open } \\
\end{array}$} & \multirow{2}{*}{$\begin{array}{c}\text { Diame- } \\
\text { ter of } \\
\text { Flower } \\
(\mathrm{cm})\end{array}$} & \multirow[b]{2}{*}{$\begin{array}{c}\text { Disc - } \\
\text { Diame- } \\
\text { ter of } \\
\text { Flower } \\
\text { (cm) }\end{array}$} & \multirow{2}{*}{$\begin{array}{c}\text { Stalk } \\
\text { Length } \\
\text { (cm) }\end{array}$} & \multirow{2}{*}{$\begin{array}{l}\text { Stalk } \\
\text { Girth } \\
(\mathrm{mm})\end{array}$} & \multirow{2}{*}{$\begin{array}{c}\begin{array}{c}\text { Number } \\
\text { of } \\
\text { Flower/ } \\
\text { Plant }\end{array}\end{array}$} & \multirow{2}{*}{$\begin{array}{c}\text { Number } \\
\text { of Flow- } \\
\text { er } / \mathrm{m}^{2}\end{array}$} & \multirow{2}{*}{$\begin{array}{c}\text { Number } \\
\text { of } \\
\text { Suckers/ } \\
\text { Plant }\end{array}$} & \multirow{2}{*}{$\begin{array}{c}\text { Vase } \\
\text { Life } \\
\text { (days) }\end{array}$} & \multirow{2}{*}{$\begin{array}{c}\text { Cost : } \\
\text { Benefit } \\
\text { Ratio }\end{array}$} \\
\hline & & 30 DAS & 60 DAS & 90 DAS & 120 DAS & & & & & & & & & & \\
\hline $\mathbf{V}_{1}$ & Regina & 21.20 & 24.89 & 30.01 & 35.62 & 83.32 & 8.47 & 2.24 & 50.27 & 10.30 & 7.36 & 63.31 & 1.25 & 6.49 & 1.25 \\
\hline $\mathbf{V}_{2}$ & Bernika & 32.58 & 37.24 & 43.51 & 49.07 & 70.75 & 11.55 & 2.59 & 57.54 & 15.29 & 10.64 & 91.47 & 2.13 & 8.40 & 1.81 \\
\hline $\mathbf{V}_{3}$ & Martyana & 28.83 & 32.53 & 38.03 & 42.26 & 74.41 & 8.52 & 2.58 & 54.16 & 13.44 & 9.77 & 83.96 & 2.00 & 8.16 & 1.66 \\
\hline$V_{4}$ & Albert & 17.04 & 20.31 & 25.51 & 31.00 & 82.17 & 8.87 & 3.22 & 47.26 & 12.71 & 7.82 & 69.31 & 2.38 & 7.28 & 1.37 \\
\hline$V_{5}$ & Salsa & 16.68 & 19.93 & 26.12 & 30.97 & 82.66 & 9.51 & 2.41 & 46.540 & 12.33 & 8.32 & 71.16 & 1.55 & 7.07 & 1.40 \\
\hline $\mathbf{V}_{6}$ & Marzena & 18.10 & 21.08 & 37.05 & 31.27 & 78.19 & 10.25 & 2.30 & 42.72 & 12.55 & 8.36 & 73.19 & 1.71 & 8.02 & 1.44 \\
\hline $\mathrm{V}_{7}$ & Marta & 15.08 & 18.52 & 23.72 & 28.47 & 86.35 & 8.00 & 2.74 & 50.58 & 10.28 & 7.69 & 67.24 & 1.34 & 6.13 & 1.33 \\
\hline$V_{8}$ & Lisiecka & 14.08 & 17.32 & 22.32 & 27.26 & 80.52 & 10.24 & 2.51 & 44.14 & 11.20 & 9.03 & 80.20 & 2.14 & 7.69 & 1.58 \\
\hline$V_{9}$ & Korman & 20.02 & 23.53 & 28.70 & 33.37 & 73.65 & 11.15 & 2.49 & 49.29 & 14.07 & 8.57 & 73.87 & 1.84 & 8.74 & 1.46 \\
\hline $\mathrm{V}_{10}$ & Pal & 14.42 & 17.54 & 22.51 & 27.64 & 83.50 & 9.05 & 2.06 & 52.40 & 9.98 & 7.94 & 69.30 & 1.81 & 6.40 & 1.37 \\
\hline \multicolumn{2}{|c|}{ F-test } & $\mathrm{S}$ & $\mathrm{S}$ & $\mathrm{S}$ & $\mathrm{S}$ & $\mathrm{S}$ & $\mathrm{S}$ & $\mathrm{S}$ & $\mathrm{S}$ & $\mathrm{S}$ & $\mathrm{S}$ & $\mathrm{S}$ & $\mathrm{S}$ & $\mathrm{S}$ & \\
\hline \multicolumn{2}{|c|}{$\mathrm{SE}(\mathrm{d})$} & 0.430 & 0.430 & 0.408 & 0.450 & 0.753 & 0.336 & 0.190 & 1.437 & 0.692 & 0.328 & 0.974 & 0.082 & 0.229 & \\
\hline \multicolumn{2}{|c|}{ C.V. } & 2.662 & 2.263 & 1.736 & 1.636 & 1.159 & 4.305 & 9.263 & 3.555 & 6.936 & 4.700 & 1.606 & 5.548 & 3.767 & \\
\hline \multicolumn{2}{|c|}{ C.D. at $5 \%$} & 0.911 & 0.911 & 0.863 & 0.953 & 1.594 & 0.711 & 0.403 & 3.041 & 1.465 & 0.695 & 2.063 & 0.174 & 0.484 & \\
\hline
\end{tabular}




\section{Quality Parameters}

In terms of Flower diameter, maximum flower diameter $(11.55 \mathrm{~cm})$ was recorded in Bernika be due to bigger ray florets which are in conformity with the findings of Singh and Ramchandran (2002) in gerbera. The bigger diameter of Corona might be due to the inherent characters of individual cultivars.

These findings are also in accordance with the results of Gotz (1983) and Jangde et al., (2019) who also reported large followed by variety Korman with $(11.15 \mathrm{~cm})$ and minimum flower diameter $(8.00 \mathrm{~cm})$ were observed in variety Marta. The size of these flowers may differences in the flower diameter of different gerbera cultivars under greenhouse conditions.

In terms of Disc-diameter, maximum Disc diameter of Flower $(3.22 \mathrm{~cm})$ was recorded in Albert followed by variety Marta with (2.74 $\mathrm{cm})$ and minimum Disc - diameter of flower $(2.06 \mathrm{~cm})$ were observed in variety $\mathrm{Pal}$. Diameter of Disc can be considered as a varietal character as it varies from variety to variety. Similar results were reported by Kumar et al., (2014) and Jangde et al., (2019).

In terms of Stalk length, maximum stalk length $(57.54 \mathrm{~cm})$ was recorded in variety Bernika followed by variety Martyana with $(54.16 \mathrm{~cm})$ and minimum stalk length $(42.72$ $\mathrm{cm})$ were observed in variety Marzena. The stalk length is a genetic factor therefore it is expected to vary among the cultivars as earlier observed by Sarkar and Ghimaray (2004) and Jangde et al., (2019). Stalk length is a very important factor for a cut flower, especially for gerbera flower. It decides the quality cut flowers. As there will be more stalk length more reserved food will be stored in the stalk which will later be available to the flower for longer time period.
In terms of Stalk girth, maximum stalk girth $(15.29 \mathrm{~mm})$ was recorded in variety Bernika followed by variety Korman with $(14.07 \mathrm{~mm})$ and minimum stalk girth $(9.98 \mathrm{~mm})$ were observed in variety Pal. The stalk girth is also a genetic factor therefore it is expected to vary among the varieties as earlier Kumar $e t$ al., (2014) and Jangde et al., (2019) reported the similar results as that of the present investigation.

In terms of vase life of flowers, maximum vase life (8.74 days) was recorded in variety Korman followed by variety Bernika with (8.40 days) and minimum vase life (6.13 days) was observed in variety Marta. The variation in vase life of flower might de due to differences in senscencing behavior of the variety by producing higher amount of ethylene formation enzymes and ethylene as reported by Jangde et al., (2019) reported the similar results as that of the present investigation.

\section{Yield Parameters}

In terms of number of flowers per plant, maximum number of flower per plant (10.64) was recorded in variety Bernika followed by variety Martyana with (9.77) and minimum number of flower per plant (7.36) was observed in variety Regina. Maximum number of flowers per plant might be attributed to the greater leaf area and more number of leaves per plant as well as plant spread would have resulted in production and accumulation of maximum photosynthesis, resulting the production of more number of flowers with bigger size. Flower yield and its quality parameter decide the significance of the particular variety, which are suitable for commercial cultivation. The results are in accordance with the findings of Sarmah et al., (2014) and Jangde et al., (2019) in gerbera under protected conditions. 
In terms of number of flowers per meter square, maximum number of flower $/ \mathrm{m}^{2}$ (91.47) was recorded in variety Bernika followed by variety Martyana with (83.96) and minimum flower yield per sq $\mathrm{m}$ (63.31) was observed in variety Regina. The higher yield might be due favorable conditions under protected conditions. Mahmood et al., (2013) and Jangde et al., (2019) reported the similar results as that of the present investigation in gerbera.

In terms of suckers/plant, maximum number of Suckers/plant (2.38) was recorded in variety Albert followed by variety Lisiecka and Bernika with (2.14) and (2.13) respectively and minimum number of Suckers/plant (1.25) was observed in variety Regina. Maximum number of suckers per plant might be attributed to the greater leaf area and more number of leaves per plant as well as plant spread would have resulted in production and accumulation of maximum photosynthesis, resulting the production of more number of suckers. Vasudevan et al., (2010) and Jangde et al., (2019) reported the similar results as that of the present investigation in gerbera.

\section{Economics}

In terms of economics, Maximum gross return (Rs. 73,176), net return (Rs. 32,681) and cost: benefit ratio (1: 1.81) was recorded in variety Bernika and minimum gross return (Rs. 50,648), net return (Rs. 10,153) and cost: benefit ratio (1: 1.25) was recorded in variety Regina.

Form the present investigation it is concluded that among the ten varieties of Gerbera. Variety Bernika found superior in Growth and yield characters followed by variety Korman and Martyana. In disc diameter and suckers yield variety Albert found superior. In vase life, Korman was superior, Minimum growth and yield was recorded in variety Marta, Pal and Regina. Maximum gross return, net return and Cost: benefit ratio was recorded in variety Bernika and minimum in variety Regina.

\section{References}

Ahlawat, T. R., Barad, A. V., Jat, G. (2012). Evaluation ofgerbera cultivars under naturally ventilated poly house.Indian Journal of Horticulture,69(4): 606 608.

Barua, U. and Bordoloi, R. (2012) Performance of gerbera cultivars under low cost polyhouse. Progressive Horticulture, 44(1): 37-39.

Gotz, W., (1983) Information of gerberas: Container culture has advantages. DeutscherGartenbau, 37(41): 18981900.

Jangde, T., Sharma, G., Jangde, B., and Banjara, N.C. (2019) Evaluation of gerbera (Gerbera jamesonii) cultivars under naturally ventilated polyhouse in Chhattisgarh plain, Journal of Pharmacognosy and Phytochemistry,8(3): 2112-2114

Kumar, S., Roy, R.K., Goel, A.K.andTewari, S.K. 2014. Comparative studies on growth and cut flowers production of gerbera under naturally ventilated polyhouse and low cost greenhouse in north eastern plains of Uttar Pradesh. Indian Journal of Horticulture, 71(4): 531-535.

Mahmood, M. A., Ahmad, N. and Khan, M. S. A. (2013) Comparative Evaluation of Growth, Yield and Quality Characteristics of Various Gerbera (Gerbera jamesonii L.) Cultivars under Protected Condition, Journal of Ornamental Plants, 3(4): 235-241.

Sarmah D, Kolukunde S, Mandal T. (2014) Evaluation of gerbera varieties for growth and flowering under polyhouse in the plains of west Bengal. 
International journal of scientific research,3(12): 2277-8179.

Singh, K.P and Ramchandaran, N. (2002). Comparision of greenhouse having natural ventilation and fan and pad evaporative cooling system for gerbera production. Journal of Ornamental Horticulture, 5(2): 15-19.

Thomas D. A., Suhatha, K., Jayanthi R., and Sangama, A. (2004) Comparative performance of sucker and tissue culture propagated plants of gerbera under poly house, Journal of Ornamental Horticulture, 7(1): 31-37.

Vasudevan, V., and Rao, V.K. (2010) Evaluation of gerbera (Gerbera jamesonii Bolus ex Hooker F.) genotypes under mid hill conditions of Garhwal Himalayas. Journal of Ornamental Horticulture, 13(3): 195199.

\section{How to cite this article:}

Akhtar, MD., Devi Singh and Urfi fatmi. 2020. Varietal Evaluation of Gerbera (Gerbera jamesonii) under Naturally Ventilated Polyhouse Condition in Prayagraj. Int.J.Curr.Microbiol.App.Sci. 9(10): 2633-2639. doi: https://doi.org/10.20546/ijcmas.2020.910.317 